\section{Acerca del tratamiento corto de neumonías en niños}

Recientemente salieron publicados en Evidencia dos trabajos paquistanies con series muy grandes de pacientes sobre tratamientos cortos en neumonías leves de niños menores de cinco años. Uno con tres días de amoxicilina vs. cinco días ${ }^{1}$ y otro sobre cotrimoxazol vs. amoxicilina (dos veces por día) durante cinco días ${ }^{2}$. El problema de ambos trabajos es su validez externa ya que en nuestro medio no hablamos de lo mismo cuando decimos neumonía. En los estudios mencionados se diagnosticó neumonia por la taquipnea. Si bien la OMS lo propone como método diagnostico, en Argentina (por lo menos por ahora) el diagnóstico de referencia es radiográgico. Si bien, la taquipnea es el mejor signo clínico (coeficiente de probabilidad positivo: $1,5-2,1$ y coeficiente de probabili-

Juan Pablo Mouesca [ Comite Editor Evidencia, Monte Grande. ] dad negativo: $0,36-0,5)$ no alcanza por sí solo para diagnosticar o descartar neumonía ${ }^{3}$. Por ejemplo, en los menores de cinco años, muchas patologias respiratorias más frecuentes que la neumonia bacteriana se presentan con taquipnea y no requieren tratamiento antibiótico. Me refiero a la bronquiolitis y a las neumonías virales en los menores de dos años y a los primeros episodios de asma en los mayores de esta edad (los autores excluyeron a los que tenían tres o más broncoespasmos). Por lo expuesto no me sorprende que no hayan encontrado diferencias y que haya habido una falla del tratamiento cercana al $20 \%$ en ambas ramas de ambos trabajos. Probablemente se trate de los pacientes que sí necesitaban antibióticos y que ni con tres ni con cinco días haya sido suficiente. Con estas evidencias, considero que no habría que innovar en el método diagnóstico, ni la duración, ni en el esquema antibiótico del tratamiento empírico inicial.

\title{
Referencias
}

1. Pakistan Multicentre Amoxicilin Short Course therapy (MASCOT) pneumonia study group. Clinical fficacy of 3 day versus 5 days of oral amoxicillin for treatment of childhood pneumonia: a multicentre doble-blind trial. Lancet 2002; 360: 835-841.

2. CATCHUP study group. Eficacia clínica del cotrimoxazol versus amoxixilina, dos veces por día, para el tratamiento de neumonía: un ensayo clinico controlado, randomizado, en Paquistán. Arch Dis Child 2002; 86: 113-118.

3. Margolis P, Gadomski A. Does this pacient have pneumonia? JAMA, 1998; 279:308-313. 